\title{
$\mathrm{ZrO}_{2}-\mathrm{SiO}_{2}$ 系ゲルの調製に及ぼす水の添加量の影響
}

\author{
鈴木 正・管野善則* \\ $\left(\begin{array}{c}\text { 福島県福島工業試験場 } \\ * \text { 山梨大学 教育学部 } \\ \text { 化学科 }\end{array}\right)$
}

\section{Effects of Amount of Added Water on the Preparation of Gels in the $\mathrm{ZrO}_{2}-\mathrm{SiO}_{2}$ System}

\author{
Tadashi SUZUKI and Yoshinori KANNO* \\ Fukushima Prefectural Industrial Research Institute \\ 1-3, Tsukenokawa, Sakurashimo, Fukushima-shi 960-21 \\ * Department of Chemistry, Faculty of Education, Yamanashi University
}

\begin{abstract}
A desired amount of water was slowly added to an equimolar solution of $\mathrm{Si}\left(\mathrm{OC}_{2} \mathrm{H}_{5}\right)_{4}$ and $\mathrm{ZrOCl}_{2} \cdot 8 \mathrm{H}_{2} \mathrm{O}$ dissolved in hot ethanol under stirring. By means of the sol-gel method, $\mathrm{ZrO}_{2}-\mathrm{SiO}_{2}$ composite materials were obtained, and the effects of amount of added water on the preparation of gels in the $\mathrm{ZrO}_{2}-\mathrm{SiO}_{2}$ system were investigated. The structure of resultant dry gel was affected by the amount of added water, and appeared in the form of fiber-like, plate-like or lump-like. With an increase of water content, a longer gelling time was required, $\mathrm{ZrSiO}$, did not crystallize in the gels even at $1500^{\circ} \mathrm{C}$. It would be important for the synthesis of $\mathrm{ZrSiO}$, to increase the interaction of Si-O bond with $\mathrm{Zr}^{4+}$.
\end{abstract}

[Received December 17, 1986 ; Accepted May 13, 1987]

Key-words : $\mathrm{ZrO}_{2}-\mathrm{SiO}_{2}$ system, Addition of water, Sol-gel method, Zircon

\section{1. 緒 言}

ゾルゲル法を利用したセラミッスの調製に関する研究 が非常に活発である. その理由は, 液相反応であるので 高純度，高均質なものが得られやすく，更に操作や装置 が簡単であり, 工程管理がしやすい, などのためである. これまでにゾルゲル法を利用して $\mathrm{ZrO}_{2}-\mathrm{SiO}_{2}$ 系化合物 の調製については, $\mathrm{ZrO}_{2}$ を結晶核形成剤とした結晶化 ガラス ${ }^{1)}$ の作製，また $\mathrm{ZrO}_{2}$ を導入することにより耐ア ルカリ性に優れた瀻維状 ${ }^{2)}$ あるいばルク状ガラス ${ }^{3)} の$ 作製, 更にジルコンの合成等が報告されている. 一方, 著者ら ${ }^{5)}$ はこれまでに, $\mathrm{ZrO}_{2}-\mathrm{SiO}_{2}$ 等モル組成粉の合成 について研究を行い熱処理温度の違いによる析出結晶相 の変化について報告してきた. それによると $\mathrm{ZrO}_{2}-\mathrm{SiO}_{2}$ 等モル組成のゲルをボールミル粉砕することにより, 正 方晶 $\mathrm{ZrO}_{2}$ と非晶質 $\mathrm{SiO}_{2}$ の選択的な反応から高純度ジ ルコンを合成することができることを明らかにした．と ころで, $\mathrm{ZrO}_{2}$ は出発溶液の組成や加水分解の方法によっ て析出する結晶相に違いが生ずることが知られてい $ろ^{6)}$. このことは, 選択的な反応を示すジルコン合成の 観点からも興味深いが, $\mathrm{ZrO}_{2}-\mathrm{SiO}_{2}$ 系における出発溶液 の組成と析出する結晶相についての報告は少ないのが現 状である. 更に出発溶液の組成の違いによるゲル構造の 変化と, 熱処理によるゲルの変化についても不明な点が 多い. 以上の観点から本研究では, オキシ塩化ジルコニ
ウムのエタノール溶液とオルトケイ酸エチルの等モル混 合溶液に蒸留水を加えてゲルを調製し，ゲルの乾燥過程 と熱処理による変化に及ぼす水の添加量の影響について 検討した. 更に熱処理による $\mathrm{ZrO}_{2}$ 結晶相の変化につい て X 線回折法によって同定したので報告する.

\section{1 原料及び溶液調製}

\section{2. 実 験}

本実験で使用した原料は, 和光純薬工業製オキシ塩化 ジルコニウムとオルトケイ酸エチルである.

使用に先立ちオキシ塩化ジルコニウム $30 \mathrm{~g}$ をタ ノールに溶解し $100 \mathrm{ml}$ のエタノール溶液とした．この エタノール溶液から $25 \mathrm{ml}$ 分取し, $300 \mathrm{ml}$ のガラスビー カーに入れマグネチックスターラーでかくはんしながら オルトケイ酸エチルをモル比で $1: 1$ になるように添加 した.この混合溶液に所定量の蒸留水 $(5,10,20,25 \mathrm{ml})$ をビューレットから滴下しかくはん混合した. 水の量は, $\mathrm{ZrO}_{2}-\mathrm{SiO}_{2}$ のモル数に対し，それぞれ $12,24,48,60$ 倍である. スターラーの回転速度はすべてのかくはんで 一定とし, 約 $5 \mathrm{~h}$ かくはん後スターラーを止め室温で放 置した. 一方, 比較のため $\mathrm{ZrO}_{2}$ 単体を次のように調製 した.オキシ塩化ジルコニウムのエタノール溶液から $10 \mathrm{ml}$ 分取しこれに蒸留水 $50 \mathrm{ml}$ 加え, これに $\mathrm{NH}_{4} \mathrm{OH}$ を添加し加水分解させて $\mathrm{ZrO}_{2}$ を得た. 


\section{2 ゲルの乾燥体と熱処理体の観察}

2.1 節で得られたゲルをガラスビーカーに時計皿でふ2 たをして 40 日間室温で自然放置し乾燥させた.この乾 燥体を光学顕微鏡 (日本光学製) を用い, 倍率 17.5 で 観察し写真撮影を行った。 またその乾燥体を管状炉（シ リコニット工業製）を用い，昇温速度 $300^{\circ} \mathrm{C} / \mathrm{h}$, 設定温 度 $1500^{\circ} \mathrm{C}$, 保持時間 $2 \mathrm{~h}, \mathrm{CO}_{2}$ と $\mathrm{H}_{2} \mathrm{O}$ を除いた清浄空 気気流中で熱処理を行った. この熱処理体も光学顕微鏡 で観察し，乾燥体との比較検討を行った。

\section{$2.3 \times$ 線回折}

水の添加量が違う熱処理体中の析出結晶の変化を粉末 $X$ 線回折法で調べた．2.2 節で得られた熱処理体をアル ミナ乳鉢で粉砕し，理学電機製ガイガーフレックスを用 い $\mathrm{Cu}$ 管球, 加速電圧 $30 \mathrm{kV}$, 電流 $15 \mathrm{~mA}$ ，ゴニオメ一 ター走査速度 $0.5^{\circ} / \mathrm{min}$ で $\mathrm{X}$ 線回折パターンを測定し相 の同定をした。

本実験においては， $2 \theta$ が $28^{\circ}$ から $32^{\circ} に$ 現れる正方 晶 $\mathrm{ZrO}_{2}$ (以下 $\mathrm{T}-\mathrm{ZrO}_{2}$ ) 之単斜晶 $\mathrm{ZrO}_{2}$ ( (以下 $\mathrm{M}-\mathrm{ZrO}_{2}$ ) の回折強度から次式により $\mathrm{T}-\mathrm{ZrO}_{2}$ の存在割合を求め t.
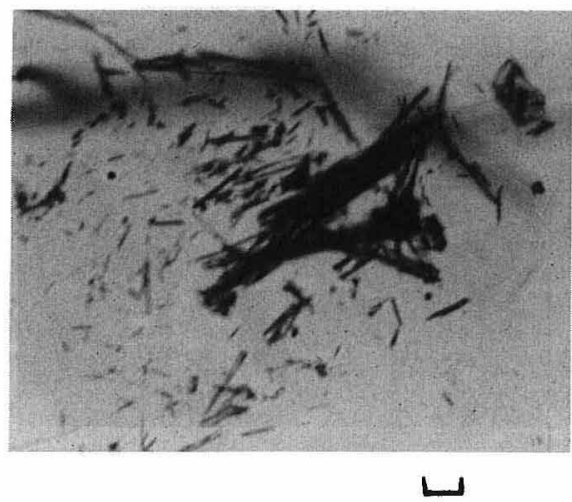

$\mathrm{H}_{2} \mathrm{O} \quad 5 \mathrm{ML}$

100رM

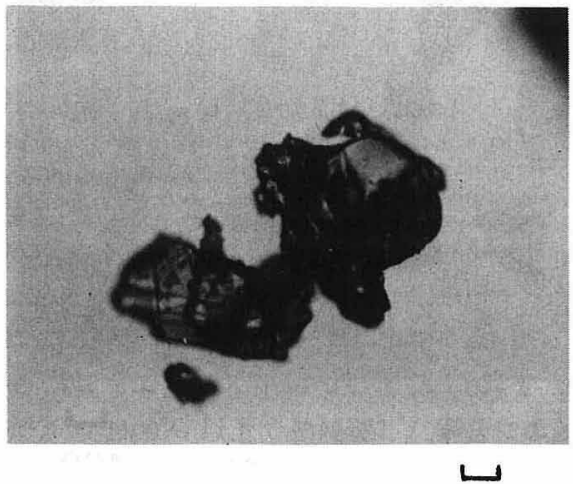

$\mathrm{H}_{2} \mathrm{O} \quad 20 \mathrm{ML}$

100נM
$\mathrm{T}-\mathrm{ZrO}_{2}$ の存在割合 $=\frac{I_{\mathrm{T}}(111)}{I_{\mathrm{M}}(111 \overline{1})+I_{\mathrm{T}}(111)+I_{\mathrm{M}}(111)}$

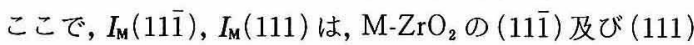
面の回折強度, $I_{\mathrm{T}}(111)$ は $\mathrm{T} \cdot \mathrm{ZrO}_{2}$ の (111) 面の回折強 度を示す。

\section{3. 実験結果及び考察}

3.1 溶液のゲル化と乾燥によるゲルの変化

所定量の蒸留水が添加された混合溶液は, 水の添加量 が多くなるにつれて粘性が低下する傾向にあり，またゲ ル化に要する時間は長くなる傾向にあった。例えば，水 を $5 \mathrm{ml}$ 添加したものは一昼夜放置後, $20 \mathrm{ml}$ 添加した ものは約 7 日後にゲル化した. 水添加量 $5,10 \mathrm{ml}$ のゲ ルは，乾燥が進むにつれ大気に接している部分から白濁 と収縮が起こり，その後き裂が発生した．水の添加量が 20, $25 \mathrm{ml}$ のゲルは, 自然放圆しても透明であった. 更 に水の添加量 $25 \mathrm{ml}$ の透明ゲルを $40^{\circ} \mathrm{C}$ の乾燥器内で 24 $\mathrm{h}$ 乾燥させても透明であった。図 1 に自然放置して得ら れた乾燥ゲルの光学顕微鏡写真を示す．図には，水の添 加量 $25 \mathrm{ml}$ のゲルは透明であるため写真撮影できなかっ

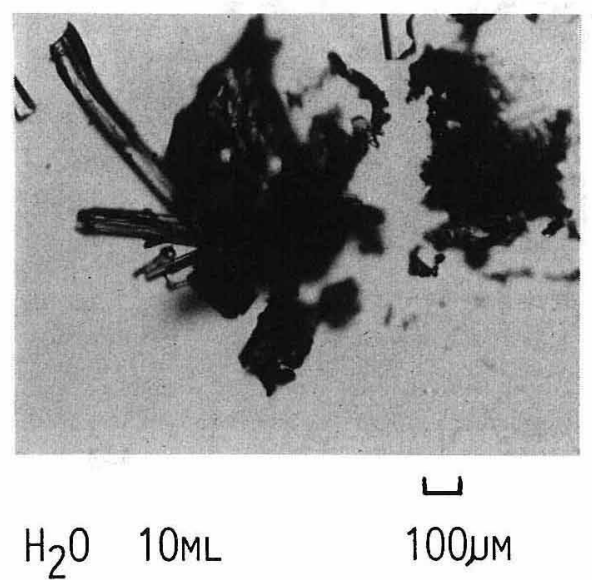

Fig. 1. Photographs of the $\mathrm{ZrO}_{2}-\mathrm{SiO}_{2}$ gels dried at room temperature. 
たので示さなかった. 写真から, 水の添加量の少ない方 が, き裂の数は多くなり繊維状の細片になることが分か る. 神谷ら”は，オルトケイ酸エチルの加水分解にお いて, 水の量がオルトケイ酸エチルとのモル比で 2 倍以 下の場合洩糸性を示し繊維を紡糸することができるが， 4 倍になると紡系は困難になり短い瀻維しか得られず, 6 倍以上になると洩系性を示さず寒天状の固化体が得ら れたと報告している. 更に加水分解途上で生成するシ口

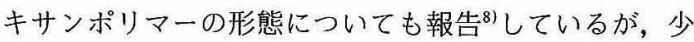
ない水の量で加水分解すると線状重合体が生成し, 多量 の水で加水分解すると球状又は 3 次元状重合体が生成し ていることを確認している. 本実験の場合も同様の結果 が得られたものと思われる. しかし，本実験における水 の量は, 神谷ら7)に比べ相対的に多く, $\mathrm{ZrO}_{2}-\mathrm{SiO}_{2}$ 系 の等モル混合溶液からバルク状物をつくるには，水の添 加量を多くする必要があるだろう。

\section{2 熱処理によるゲルの変化}

得られた乾燥ゲルを, 昇温速度 $300^{\circ} \mathrm{C} / \mathrm{h}$, 設定温度 $1500^{\circ} \mathrm{C}$ で熱処理したときの顕微鏡写真を図 2 に示す。

図 1 と比較するとほぼ同じ形状を保っているが，水の添
加量が $20,25 \mathrm{ml}$ のものは，透明体から不透明体になつ た.これは, 通常のゾルゲル法の昇温速度に比べ速かっ たために微小な気孔やき裂が生成したものと考えられ る. 更に水の添加量が $5 \mathrm{ml}$ のものを熱処理したゲルは, 透明な固化体と白色不透明固化体が全体的に観察され, $\mathrm{SiO}_{2}$ と $\mathrm{ZrO}_{2}$ に分離しているものと考えられる.このこ とは，水の添加量が少ない場合，オルトケイ酸エチルは 線状重合体になっておりその重合体に $\mathrm{Zr}^{4+}$ が配位した 構造をしているものと推察される.

\section{$3.3 \mathrm{X}$ 線回折}

熱処理して得られたゲルの X 線回折パターンを図 3 に示す、ただし図 3 では, 前報5)で示したエタノール のみの溶液からなるゲルの回折パターンも併せて示し た.この回折パターンから，いずれの水の量においても $\mathrm{T}-\mathrm{ZrO}_{2}$ と $\mathrm{M}-\mathrm{ZrO}_{2}$ の結晶のみが析出しており, $\mathrm{ZrO}_{2}-$ $\mathrm{SiO}_{2} 2$ 成分系のものは析出していない.この回折パター ンから, 水の添加量が多くなるにつれて $\mathrm{M}-\mathrm{ZrO}_{2}$ 相が減 少していくのが分かる. そこで，水の添加量の違いによ る $\mathrm{T}-\mathrm{ZrO}_{2}$ と $\mathrm{M}-\mathrm{ZrO}_{2}$ の相対強度の変化についてプロッ トしたのが, 図 4 である. 比較のために行った $\mathrm{ZrO}_{2}$ 単

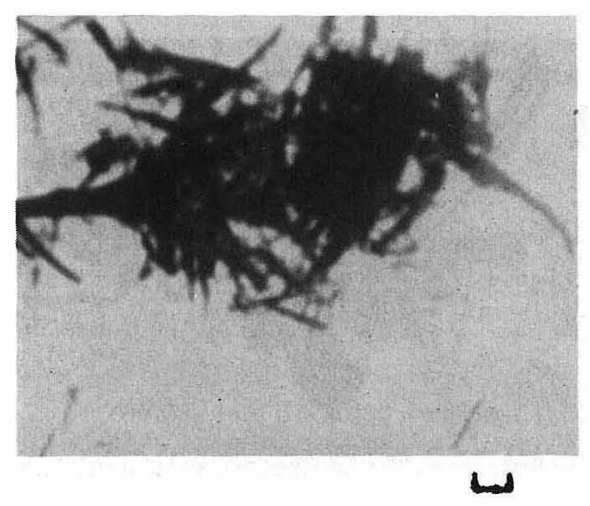

$\mathrm{H}_{2} \mathrm{O}$ 5ML $\quad 100 \mathrm{NM}$

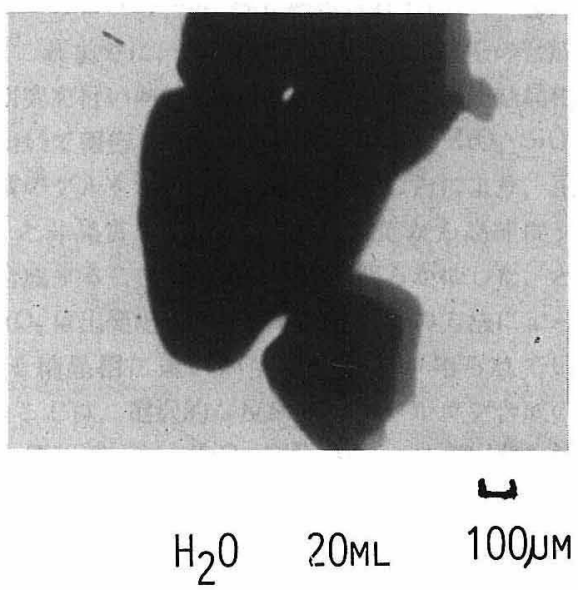

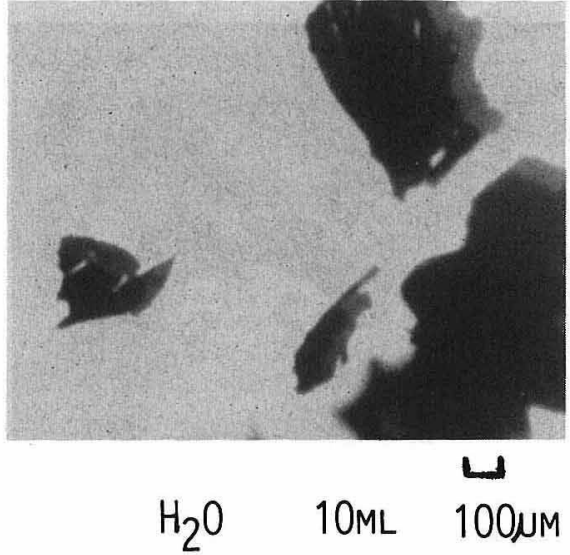

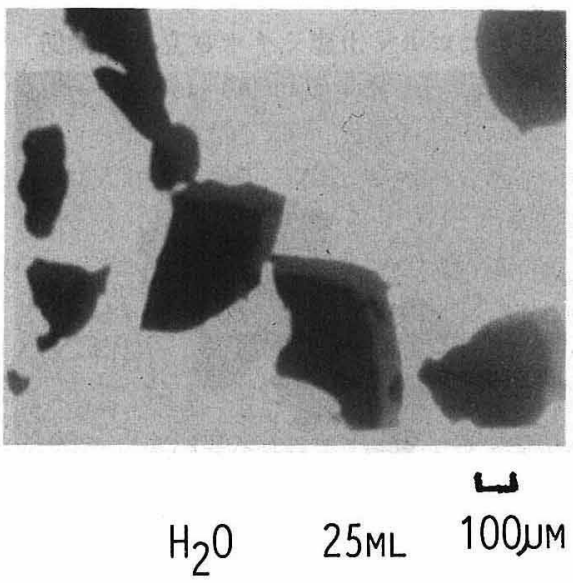

Fig. 2. Photographs of the $\mathrm{ZrO}_{2}-\mathrm{SiO}_{2}$ mixture calcined at $1500^{\circ} \mathrm{C}$ for $2 \mathrm{~h}$. 


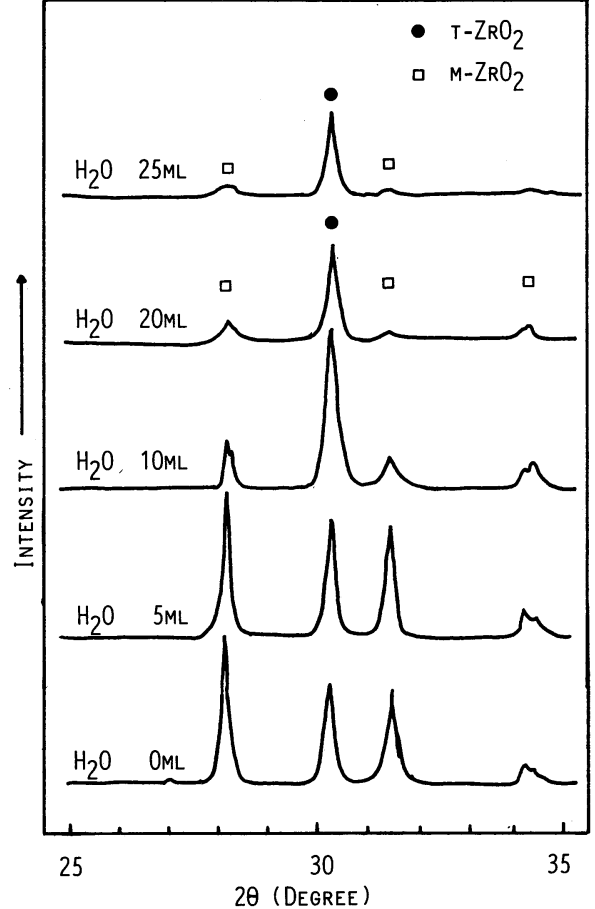

Fig. 3. X-ray diffraction patterns of powders calcined at $1500^{\circ} \mathrm{C}$ for $2 \mathrm{~h}$.

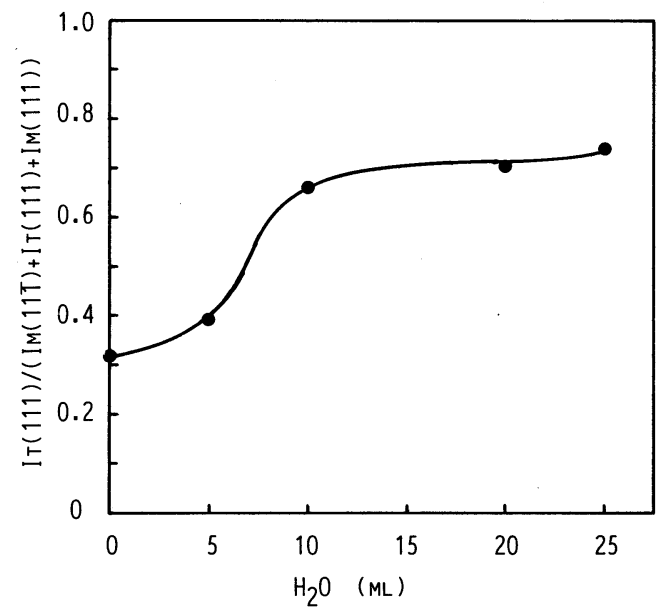

Fig. 4. Variation of $I_{\mathrm{T}}(111) /\left(I_{\mathrm{M}}(11 \overline{1})+I_{\mathrm{T}}(111)+\right.$ $\left.I_{M}(111)\right)$ of powders calcined at $1500^{\circ} \mathrm{C}$ for $2 \mathrm{~h}$ plotted against the amount of added $\mathrm{H}_{2} \mathrm{O}$.

体の回折パターンにおいては, 熱処理温度が $400^{\circ} \mathrm{C}$ 以 下のときは $\mathrm{T}-\mathrm{ZrO}_{2}$ 単相, 温度上昇に伴い, $\mathrm{M}-\mathrm{ZrO}_{2}$ が 析出し始め, $1500^{\circ} \mathrm{C}$ のときは $\mathrm{M}-\mathrm{ZrO}_{2}$ 単相であった. 更に神谷ら ${ }^{2)}$ は, $\mathrm{ZrO}_{2}-\mathrm{SiO}_{2}$ 系については $\mathrm{ZrO}_{2}$ が 26 $\mathrm{wt} \%$ 以上でかつ $1100^{\circ} \mathrm{C}$ 以上で熱処理した場合にのみ $\mathrm{M}-\mathrm{ZrO}_{2}$ が析出することを示している. 以上のことと, 本実験の場合とは異なった傾向を示しているが，次のよ うに考察されよう.すなわち，3.1節にも述べたように
水の添加量によってオルトケイ酸エチルは, 線状重合体 から 3 次元又は球状重合体に変化しているが, $1500^{\circ} \mathrm{C}$ に加熱しても $\mathrm{ZrO}_{2}-\mathrm{SiO}_{2} 2$ 成分系の結晶が析出していな いことから考えると, ゲル体には Si-O-Zr の結合は存在 していないと推察される. したがって水の添加量が少な い場合は, $\mathrm{Si}-\mathrm{O}$ 線状重合体の骨格構造の周りに $\mathrm{Zr}^{4+}$ が 弱く配位し, 多い場合は $\mathrm{Si}-\mathrm{O} 3$ 次元重合体の網目構造 になり $\mathrm{Zr}^{4+}$ イオンは, その網目構造の空げきの位置に 入っていると考えられる.これを熱処理すると線状重合 体の周りに配位している $\mathrm{Zr}^{4+}$ は，粒成長を起こし， M$\mathrm{ZrO}_{2}$ に転移しやすくなるものと考えられる. 一方， 3 次元網目構造の空げき位置に入っている $\mathrm{Zr}^{4+}$ は, $\mathrm{SiO}_{2}$ 之 $\mathrm{ZrO}_{2}$ に分相しやすく, その結果生成した $\mathrm{ZrO}_{2}$ 粒子 は, $\mathrm{SiO}_{2}$ の骨格に囲まれた構造をしており，更に微細 な粒子と推察されるが今後の確認が必要である.

$\mathrm{T}-\mathrm{ZrO}_{2}$ の室温安定性に関しては, 粒径効果とマトリッ クス効果が知られている ${ }^{91}$.つまり, 生成した微細な $\mathrm{ZrO}_{2}$ 粒子は, 過剰な表面エネルギーを持ち, 表面エネ ルギーの低い $\mathrm{T}-\mathrm{ZrO}_{2}$ が安定に存在し, 更にマトリック スと $\mathrm{ZrO}_{2}$ のひずみエネルギーが増すことによって $\mathrm{T}$ 相 から $\mathrm{M}$ 相への転移を抑制していると考えられている. 本実験の結果は, 上述と同様の理由により水の添加量が 多くなるほど， $\mathrm{T}-\mathrm{ZrO}_{2}$ が安定に存在しているものと考 えられる，著者らは，前報占において $\mathrm{T}-\mathrm{ZrO}_{2}$ と非晶質 $\mathrm{SiO}_{2}$ からジルコンが合成できることを示したが，本研 究の場合 $\mathrm{T}-\mathrm{ZrO}_{2}$ の析出が多いわりにはジルコンの生成 が進行しなかった. ジルコン合成という観点から考える 之, $\mathrm{Si}-\mathrm{O}$ と $\mathrm{Zr}^{4+}$ の相互作用性を高める必要があるもの と考えられる. 以上のことから図 4 を考察すると水の添 加量が $5 \mathrm{ml}$ から $10 \mathrm{ml}$ の間で急激に $\mathrm{T}-\mathrm{ZrO}_{2}$ が生成し ていることから，この間に Si-O 結合が線状から 3 次元 状重合体に遷移しているものと推察される.

\section{4. 総 括}

オキシ塩化ジルコニウムのエタノール溶液とオルトケ イ酸エチルの $1: 1$ モル組成からなる混合溶液にそれぞ れ水を $5,10,20,25 \mathrm{ml}$ 加え, 混合後, 自然放置しゾ ルゲル法により固化体及び $\mathrm{ZrO}_{2}-\mathrm{SiO}_{2}$ 系からなる熱処 理体を得た．その結果以下のことが分かった.

（1）混合溶液は，水含有量が多くなるにつれてゲル 化に要する時間が長くなり, き裂の数は少なく透明体に なる傾向があった．また水の含有量により繊維状, 塊状 のものが得られた.

（2）熱処理したゲルは, 乾燥体の形状を保ってお り, 結晶相は, 水の添加量が多くなるにつれて $\mathrm{T}-\mathrm{ZrO}_{2}$ 相が増加する傾向にあった。

（3）ゾルゲル法で得た乾燥体をそのまま熱処理して もジルコンは生成しなかった．ジルコンを合成するため 
には, $\mathrm{Si}-\mathrm{O}$ と $\mathrm{Zr}{ }^{4+}$ の相互作用性を高めることが必要で あると推察された。

\section{文献}

1) M. Nogami and M. Tomozawa, J. Am. Ceram. Soc., 69, 99-102 (1986).

2）神谷寛一，横尾俊信，岩中雅文，坂井章人，作花済夫，“ジ ルコニアセラミックス，5”，宗宮重行，吉村昌弘編，内 田老鶴圃 (1985) pp. 39-52.
3）野上正行, 善協, 93，195-200 (1985).

4）門側幸宏, 山手 有, 窯協, 93，338-40 (1985).

5）管野善則，鈴木 正，材料誌投稿中.

6）例 え ば, R.C. Garvie, J. Phys. Chem., 69, 1238 (1965).

7）神谷寛一, 作花済夫，水谷通利，窯協， 86，552-59 (1978).

8）神谷寛一, 横尾俊信, 作花済夫, 宰協, 92, 242-47 (1984).

9）島田昌彦, 佐藤次雄, 化学亡工業, 37, 790-91 (1984).

\section{論文募集——「超伝導セラミックス」}

窯業協会誌第 6 回特集号

\section{苇業協会誌編集委員会}

セラミックス高温超伝導体の出現により超伝導の研究が白熱化している. 現時点で今後の方向を明確化する ことはまだ難しいが, $T_{\mathrm{c}}$ の競争だけでなく，七ラミックスの科学と工学の立場からのセラミックス超伝導体 の研究もまた非常に重要である.このような観点から, セラミックス超伝導体に関する物性, 構造, 反応, 合 成, 加工, 応用などの広範囲の論文を募集します。内容範囲は一応, 酸化物系に限定しますが, 必ずしも $T_{\mathrm{c}}$ やマイスナー効果の測定を含む必要はありません.

$$
\text { 一記 一 }
$$

原 稿 締切：昭和 62 年 11 月 20 日（金）必着. 厳守願います. 遅れた場合は一般論文扱いとなります.

原稿の種類：論文及びノート (投稿規程参照, 英文での投稿歓迎)

原稿の長さ：図表を含め会誌刷り上がり論文は 5 ページ，ノートは 3 ページ以内を原則とします（会誌 1 ペー ジは 250 字詰原稿用紙 9.6 枚, 英文の場合は A4 判の用紙に 1 行 60 字，ダブルスペース 28 行で 2.5 枚，あるいは図表約 6 枚に相当します).

内 容: 上記の分野における研究で, 印刷物として未発表のもの.

予 約：昭和 62 年 11 月 10 日 (火) までに投稿予定原稿の種類と標題及び 50 字以内の要旨を 1 件ごとに 1 枚の葉書で嘿業協会誌編集委員会にお知らせ下さい。

審查：通常の样業協会誌への投稿論文と同様の審査を行いますが，論文 (揭載等) の取り扱いについて は編集委員会に御一任願います。

揭載：昭和 63 年 4 月号又は 5 月号 (予定).

原稿執筆に当たっては窯業協会誌投稿規程 (窯業協会誌 1986 年 12 月号) を御覧下さい. ワードプロセッサー 利用の場合は窯業協会誌 1987 年 4 月号に原稿の作成方法が揭載されています。また，投稿原稿の表紙に特集 号「超伝導セラミックス」と明記して下さい. 